\title{
Corticotrophin Releasing Hormone; As a Useful Marker to Identify the Pre-eclampsia
}

Salma Farukh Memon, Zulfiqar Ali Laghari, Shakil Ahmed Shaikh, Muhammad Ali Bhatti

\begin{abstract}
OBJECTIVE: To determine the corticotrophin releasing hormone as a diagnostic marker of preeclampsia METHODOLOGY: Prospective cross sectional study included 100 pregnant women diagnosed as a case of pre-eclampsia recruited from antenatal clinics; 100 normal healthy pregnant women were inducted as controls. Maternal blood samples were collected for CRH level at 31 to 33 weeks of gestation on routine antenatal visits. Estimation of CRH was done by ELSIA method used Enzyme linked Immunoassay (EIA) technique done on Diamet Elizer system using commercially available kit. All the data was recorded in the proforma for the purpose of analysis by SPSS v.16.0.

RESULTS: Mean age of controls was $23.66 \pm 4.02$ years, while in cases participants $23.82 \pm 3.6$ years. Mean CRH was found significantly higher in cases $60.01 \pm 9.94 \mathrm{ng} / \mathrm{ml}$ as compare to controls $49.26 \pm 9.39 \mathrm{ng} / \mathrm{ml}$, P-value 0.001 . Mean Protein urea was found significantly higher in cases $0.65 \pm 0.117 \mathrm{~g}$ than control $0.08 \pm 0.04 \mathrm{~g}$. Blood pressure was significantly high in cases as compare to control, $P=0.001$

CONCLUSION: We concluded that CRH level is the good predictor of preeclampsia.
\end{abstract}

KEY WORDS: Preeclampsia, CRH

This article may be cited as: Memon SF, Laghari ZA, Shaikh SA, Bhatti MA. Corticotrophin Releasing Hormone; As a Useful Marker to Identify the Preeclampsia. J Liaquat Uni Med Health Sci. 2018;17(03):157-60. doi: 10.22442/jlumhs.181730569

\section{INTRODUCTION}

Preeclampsia is one of the most common pregnancy related disorder, affecting $2 \%$ to $8 \%$ of all pregnancies around the world ${ }^{1}$. Pre-eclampsia is diagnosed at third trimester of pregnancy after 20 weeks of gestation; diagnosed criteria include raised blood pressure $\geq$ $140 / 90 \mathrm{mmHg}$ with two different times within $\geq 4$ hour's duration and elevated level of protein urea $\geq 0.3 \mathrm{~g} / 24$ hrs collection ${ }^{2}$.

The placenta usually forms during pregnancy to provide nutrient, causing development of fetus and growth of the fetus. Abnormal placental formation due to restricted growth of trophoblast cells into the uterus may lead to failure of remodeling of maternal spiral arteries is believed to be the cause of preeclampsia ${ }^{3}$. Preeclampsia characterized by deficient placentaion causing hypoxia of placenta which further causes secretion of pro-inflammatory cytokines leading to release of antiangiogenic and angiogenic factors and miRNAS. Other factors like activation of neutrophils and endothelial damage stimulating activity of aggregation and adhesion, pathophysiology of pre-eclamsia ${ }^{4}$.

Corticotrophin releasing hormone $(\mathrm{CRH})$ is a peptide in nature, containing 41 amino acid, $\mathrm{CRH}$ secreted from paraventricular nucleus of hypothalamus in response to stress and also present in conditions that causing inflammation ${ }^{5}$. In non-pregnant women, CRH is undetectable while during pregnancy it increases 100-1000 times in maternal blood. From the start of $2^{\text {nd }}$ trimester $\mathrm{CRH}$ increases rapidly to reach approximately $800 \mathrm{pg} / \mathrm{ml}$ in third trimester ${ }^{6}$. CRH becomes undetectable in maternal and fetal blood 24 hours after the end of pregnancy, 8 .

Recent studies revealed that $\mathrm{CRH}$ level has negative correlation with the length of gestation and leads to preterm birth ${ }^{9}$. CRH plays vital role in pathogenesis of pre-eclampsia ${ }^{10}$. Increased levels of $\mathrm{CRH}$ affects $\mathrm{CRH}-\mathrm{R}$ receptors, $\mathrm{CRH}-\mathrm{R}$ receptor can be used as a biomarker for prediction of preeclampsia ${ }^{11}$.

\section{METHODOLOGY}

In this prospective cross sectional study, we used probable Simple Random technique for sample collection. Approval to carry out of this study was obtained from ethical review committee. Study carried out from June 2016 to September 2017. One hundred pregnant women with diagnosed pre-eclampsia were recruited from antenatal clinics of various hospitals of Hyderabad city, as cases and one hundred pregnant women without pre-eclampsia was similarly investigated as controls. A proforma was used for demographic data, medical history and physical examination of all the selected pregnant women with and without preeclampsia. Preeclampsia was defined 
as; two different readings blood pressure $\geq 140 / 90$ $\mathrm{mmHg}$ with $\geq$ 4hours.Participants with history of hypertension before the pregnancy, obese women, endocrinal disorders and those were not agreed to participate in the study were excluded. After volunteer consent for blood sample collection and physical examination, all the subjects were studied for hemodynamic recording, and physical signs of anemia, jaundice, edema, and LMP, EDD, ultrasound findings for pregnancy. Maternal blood samples were collected during routine antenatal visits at 31-33 week of gestation. Venous blood samples $06 \mathrm{ml}$ in each in two heparinized tubes were collected for Blood CP, Glucose, Proteins in urine, and after centrifuged machine by Thermo Heraeus lebofuge at 400 for 05 minutes at $4^{\circ} \mathrm{C}$, the plasma was separated, labelled and stored at $-20^{\circ}$ Celsius until assayed for $\mathrm{CRH}$. Estimation of $\mathrm{CRH}$ was done by ELISA method Immunoassay using commercially available kit EIA-1631 manufactured by DRG International Inc., USA and provided by Global Marketing Services Rawalpindi. It was performed Diamet. ELIZA plate reader machine. All the data was recorded in the Performa for the purpose of analysis by SPSS v. 16.0.

\section{RESULTS}

In this cross sectional comparative study, out of 200 only 186 participated with the response rate of $93 \%$ among them $n=91$ cases and $n=95$ control, mean age of cases (pre-eclampsia) was $23.82 \pm 03.6$ years with range of minimum 20 years and maximum 30 years while mean age in control was $23.66 \pm 4.02$ years with range of minimum 20 years and maximum 30 years. No statistically significant difference was found in mean age of both groups $P=0.76$. Mean systolic blood pressure in cases was $150.35 \pm 7.67 \mathrm{mmHg}$ while in control was $122.79 \pm 9.08 \mathrm{mmHg} P=0.001$. Mean Diastolic blood pressure in cases was $98.94 \pm 7.03 \mathrm{mmHg}$ while in control was $80.23 \pm 6.26 \mathrm{mmHg}, P=0.001$ shows in Table $\mathrm{I}$.

In this study $\mathrm{CRH}$ was found significantly higher in cases $60.01 \pm 9.94 \mathrm{ng} / \mathrm{ml}$ as compare to control $49.26 \pm 9.39 \mathrm{ng} / \mathrm{ml}, P=0.001$. Mean proteinuria was found significantly elevated in cases $0.65 \pm 0.117 \mathrm{~g} / 24 \mathrm{hrs}$ and in controls $0.08 \pm 0.04 \mathrm{gl} 24$ hrs. Mean systolic and diastolic blood pressure in controls $120.90 \pm 7.46 \mathrm{mmHg}$ and $79.60 \pm 5.80 \mathrm{mmHg}$ respectively, while in cases systolic BP $149.80 \pm 7.58 \mathrm{~mm} \mathrm{Hg}$ and diastolic BP $98.00 \pm 6.89 \mathrm{mmHg}$. Blood pressure was significantly higher in women diagnosed with pre-eclampsia as compare to normal women $P=0.001$. Table II
TABLE I:

BASIC CHARACTERISTICS OF PARTICIPANTS

\begin{tabular}{|l|c|c|c|}
\hline \multicolumn{1}{|c|}{ Variables } & $\begin{array}{c}\text { Cases } \\
(\mathbf{n = 9 1 )} \\
\text { Mean } \pm \text { Std }\end{array}$ & $\begin{array}{c}\text { Control } \\
(\mathbf{n = 9 5 )} \\
\text { Mean } \pm \text { Std }\end{array}$ & P-Value \\
\hline Age & $23.84 \pm 3.87$ & $23.88 \pm 4.02$ & 0.769 \\
\hline $\begin{array}{l}\text { Systolic BP } \\
(\mathrm{mmHg})\end{array}$ & $150.35 \pm 7.67$ & $122.79 \pm 9.08$ & 0.001 \\
\hline $\begin{array}{l}\text { Diastolic BP } \\
(\mathrm{mmHg})\end{array}$ & $98.94 \pm 7.03$ & $80.23 \pm 6.26$ & 0.001 \\
\hline
\end{tabular}

TABLE II: DISTRIBUTION OF PARTICIPANTS ACCORDING TO CRH LEVEL, PROTEINUREA AND GESTATIONAL LENGTH

\begin{tabular}{|l|c|c|c|}
\hline \multicolumn{1}{|c|}{ Variables } & $\begin{array}{c}\text { Cases } \\
(\mathbf{n}=\mathbf{9 1})\end{array}$ & $\begin{array}{c}\text { Control } \\
(\mathbf{n = 9 5 )}\end{array}$ & $\boldsymbol{P}$-Value \\
\hline $\mathrm{CRH}(\mathrm{ng} / \mathrm{ml})$ & $60.33 \pm 10.479$ & $50.033 \pm 9.339$ & 0.001 \\
\hline $\begin{array}{l}\text { Proteinuria } \\
\text { (g/ 24hrs) }\end{array}$ & $0.65 \pm 0.117$ & $0.08 \pm 0.04$ & 0.001 \\
\hline $\begin{array}{l}\text { Gestational } \\
\text { Length(weeks) }\end{array}$ & $37.477 \pm 1.160$ & $42.012 \pm 1.754$ & 0.001 \\
\hline
\end{tabular}

\section{DISCUSSION}

Pre-eclampsia is a pregnancy related complication, a life threatening condition. Pre-eclampsia increases the risk of maternal and fetal mortality and morbidity. Preeclampsia is associated with increased $\mathrm{CRH}$ levels in maternal blood. $\mathrm{CRH}$ is not detectable in normal women and men. $\mathrm{CRH}$ becomes detectable in pregnancy due to stress and in preeclampsia; it increases from the start of second trimester and reaches to peak on the $3^{\text {rd }}$ trimester of pregnancy. Increased $\mathrm{CRH}$ levels complicate the pregnancy and causing preterm labor. Similarly in our study $\mathrm{CRH}$ level was significantly high in cases as compare to control $P=0.001$.A study in university of California ${ }^{12}$ revealed similar results increase $\mathrm{CRH}$ level in preeclampsia.

In our study, out of 200 participants 186 finally recruited with response rate of $93 \%$, mean age of cases were $23.84 \pm 3.87$ and $23.88 \pm 4.02$ in controls with no any significant difference $P=0.769$. A Study conducted with no age difference was found in both groups. In a study conducted in Iran which investigates anxiety in preeclampsia and in normal pregnancy which differ with age group of our study. Mean systolic blood pressure and diastolic blood pressure was found in normal control was $122.79 \pm 9.08 \mathrm{mmHg}$ and $80.23 \pm 6.26 \mathrm{mmHg}$, while in cases systolic blood pressure $150.35 \pm 7.67 \mathrm{mmHg}$ and diastolic blood pressure $98.94 \pm 7.03 \mathrm{mmHg}$, with 
significant difference $P=0.001$ Similarly in another Pakistani study ${ }^{13}$ reported that mean systolic blood pressure incases $150.12+7.67 \mathrm{mmHg}$ while in control $122.79+9.08 \mathrm{mmHg}$. It indicates significant difference between both case and control groups.

In this study, the mean plasma $\mathrm{CRH}$ value in cases was $60.63+10.74 \mathrm{ng} / \mathrm{ml}$ and that in control $50.30+9.36 \mathrm{ng} / \mathrm{ml}$; it indicates $\mathrm{CRH}$ levels were significantly raised in cases than controls. Similarly significant difference of $\mathrm{CRH}$ levels were found in other studies as well ${ }^{8,14,15}$.

Presence of protein in urine is considered to be abnormal condition in pregnancy, levels of Proteinuria $\geq 300 \mathrm{~g} / 24 \mathrm{hrs}$ at any stage of pregnancy. Proteinuria in cases $0.65 \pm 0.117 \mathrm{~g} / 24 \mathrm{hrs}$ while in control $0.08 \pm 0.04$ this results shows resemblance study conducted in past $^{16}$.

In this research, the length of gestation is inversely correlated with cases as compared to control group. Preeclampsia is one of the major causes of preterm birth. Length of gestation was found in cases was $37.477 \pm 1.160$ weeks while in control $42.012 \pm 1.754$ weeks, similar result found in other study ${ }^{17}$.

\section{CONCLUSION}

We concluded that $\mathrm{CRH}$ level is the good predictor for preeclampsia, it should be diagnosed during antenatal care of early pregnancy, to evaluate the early diagnosis of pre-eclampsia. By this early knowledge may reduce the maternal and fetal morbidity and mortality associated to pre-eclampsia.

CONFLICT OF STUDY: No any conflict

FUNDING: Self-funding

\section{REFERENCES}

1. English FA, Kenny LC, McCarthy FP. Risk factors and effective management of preeclampsia. Integr Blood Press Control 2015; 8: 7-12 . doi: 10.2147/ IBPC.S50641.

2. Zeisler H, Llurba $E$, Chantraine $F$, Vatish $M$, Staff $A C$, Sennstrom $M$, et al. Predictive value of the sFlt-1: PIGF ratio in women with suspected preeclampsia. New Engl J Med 2016; 374(1): 13-22. doi: 10.1056/NEJMoa1414838.

3. Ji L, Brkić J, Liu M, Fu G, Peng C, Wang YL. Placental trophoblast cell differentiation: physiological regulation and pathological relevance to preeclampsia. Mol Aspects Med. 2013; 34(5):981-1023. doi: 10.1016/j.mam.2012.12.008.

4. Laresgoiti-Servitje E. A leading role for the immune system in the pathophysiology of preeclampsia. J leukoc Biol 2013; 94(2): 247-57. doi: 10.1189/jlb.1112603.

5. Hollenstein K, Kean J, Bortolato A, Cheng RK,
Dore AS, Jazayeri A, et al. Structure of class B GPCR corticotropin-releasing factor receptor 1 . Nature 2013;499(7459):438-43. doi: 10.1038/ nature12357.

6. Hannerfors AK, Hellgren C, Schijven D, Iliadis SI, Comasco E, Skalkidou A, et al. Treatment with serotonin reuptake inhibitors during pregnancy is associated with elevated corticotropin-releasing hormone levels. Psychoneuroendocrinology 2015; 58: 104-113. doi: 10.1016/j.psyneuen.2015.04.009.

7. Goland RS, Conwell IM, Jozak S. The effect of pre-eclampsia on human placental corticotrophinreleasing hormone content and processing. Placenta 1995; 16(4): 375-382. DOI: 10.1016/0143-4004(95)90095-0

8. Meltzer-Brody S, Stuebe A, Dole N, Savitz D, Rubinow D, Thorp J. Elevated corticotropin releasing hormone $(\mathrm{CRH})$ during pregnancy and risk of postpartum depression (PPD). J Clin Endocrinol Metabol 2011; 96(1): E40-E47. doi: 10.1210/jc.2010-0978

9. Petraglia F, Imperatore A, Challis JR. Neuroendocrine mechanisms in pregnancy and parturition. Endocr Rev. 2010; 31(6): 783-816. doi: 10.1210/ er.2009-0019.

10. Aziz MA, Krisnadi SR, Effendi JS, Rohmat R. Correlation of Nitric Oxide (NO) and Corticotrophin Releasing Hormone (CRH) between Normal Pregnancy and Preeclampsia. Open J Obstet Gynecol 2016; 6(13): 807-817. DOI: 10.4236/ojog.2016.613099

11. Grammatopoulos DK. Placental CorticotrophinReleasing Hormone and its Receptors in Human Pregnancy and Labour: Still a Scientific Enigma. J Neuroendocrinol 2008; 20(4): 432-38. doi: 10.1111/j.1365-2826.2008.01660.x.

12. Sandman CA, Glynn L, Schetter CD, Wadhwa P, Garite T, Chicz-DeMet A, et al. Elevated maternal cortisol early in pregnancy predicts third trimester levels of placental corticotropin releasing hormone $(\mathrm{CRH})$ : priming the placental clock. Peptides 2006; 27(6):1457-63.

13. Memon SF, Ansari AK, Fatima S. Evaluation Of Corticotropin Releasing Hormone (CRH) In Preeclampsia. PAFMJ 2010; 60(4): 591-4 .

14. Kramer MS, Lydon J, Séguin L, Goulet L, Kahn $\mathrm{SR}$, McNamara $\mathrm{H}$, et al. Stress pathways to spontaneous preterm birth: the role of stressors, psychological distress, and stress hormones. Am J Epidemiol 2009; 169(11): 1319-26. doi: 10.1093/ aje/kwp061.

15. Guendelman S, Kosa JL, Pearl M, Graham S, Kharrazi M. Exploring the relationship of 
second-trimester corticotropin releasing hormone, chronic stress and preterm delivery. J Matern Fetal Neonatal Med 2008; 21(11): 788-95. doi: $10.1080 / 14767050802379031$.

16. Garovic VD, Wagner SJ, Turner ST, Rosenthal DW, Watson WJ, Brost BC, et al. Urinary podocyte excretion as a marker for preeclampsia. Am
J Obstet Gynecol 2007; 196(4): 320. e1-e7.

17. Gillman MW, Rich-Edwards JW, Huh S, Majzoub JA, Oken E, Taveras EM, et al. Maternal Corticotropin-Releasing Hormone Levels during Pregnancy and Offspring Adiposity. Obesity(Silver Spring) 2006; 14(9): 1647-53.

AUTHOR AFFILIATION:
Dr. Salma Farukh Memon (Corresponding Author)
Associate Professor, Department of Physiology
Liaquat University of Medical and Health Sciences
Jamshoro, Sindh-Pakistan.
Cell Number: 03327914091
Email: memon_salma@hotmail.com
Dr. Zulfiqar Ali Laghari
Professor, Department of Physiology
University of Sindh Jamshoro, Sindh-Pakistan.
Dr. Shakil Ahmed Shaikh
Department of Physiology
CMH Hyderabad, Sindh-Pakistan.
Dr. Muhammad Ali Bhatti
CMH Hyderabad, Sindh-Pakistan.

